\title{
Muslim Parents' Ways in Providing Sex Education and Guidance for Teenagers
}

\section{Desya Safitri ${ }^{1} \mid$ Siti Hulaiyah ${ }^{2}$}

\section{${ }^{1}$ Student of BPI Study Program UIN Syarief Hidayatulah Jakarta \\ ${ }^{2}$ Student of BPI Study Program UIN Syarief Hidayatulah Jakarta}

\section{Korespondensi}

desya.safitri21@mhs.uinjkt.ac .id

siti.hulaiyah21@mhs.uinjkt.ac. id

\begin{abstract}
Abstrak
Artikel ini bertujuan untuk memberikan pola pemahaman kepada orang tua muslim bahwa bimbingan pendidikan seks sangat diperlukan bagi remaja. Dengan memberikan pemahaman dan bimbingan tentang pendidikan seks dalam konteks Islam, diharapkan remaja dapat tumbuh menjadi generasi muda yang beriman dan bertakwa kepada Allah SWT, serta mampu menjaga kesucian dirinya. Jenis penelitian yang digunakan adalah metode deskriptif kualitatif, datanya berasal dari survei kuesioner orang tua muslim dengan 46 responden. Hasil penelitian ini menunjukkan bahwa masih banyak orang tua yang merasa asing dan tabu tentang pendidikan seks remaja. Orang tua menganggap pendidikan seks harus dilakukan sebagai orang dewasa dan diberitahu oleh guru di sekolah.
\end{abstract}

\section{KATA KUNCI:}

Pendidikan seks, Remaja, Orangtua Muslim. 


\begin{abstract}
This article aims to provide a pattern of understanding to Muslim Parents that sex education guidance is very necessary for teenagers. By providing understanding and guidance on sex education in the context of Islam, it is hoped that adolescents can grow into young people who believe and fear Allah SWT, and can maintain their own chastity. The type of research used is the descriptive qualitative method, the data comes from a questionnaire survey of Muslim Parents with 46 respondents. The results of this study indicate that there are still many parents who feel foreign and taboo about adolescent sex education. Parents consider sex education to be done as adults and told by teachers at school.

KEYWORDS:

Sex education, In teenagers, Muslim Parents.
\end{abstract}




\section{1 | Introduction}

In the journal Reny (2019) states that sex education is a knowledge what we teach about everything to do with gender. This includes starting from the growth of gender (male or female). How does the sex function as a means of reproduction. How is the development of the genitals in women and in men. About menstruation, wet dreams and so on, to the onset of lust due to changes in hormones. Including later the problem of marriage, pregnancy and so on [1].

According to Sarlito in his book Adolescent Psychology in general Sexual education is a clear and correct information regarding the problem of human sexuality, which includes the process of conception, pregnancy to birth, sexual behavior, and aspects of health, psychology and society. As according to Abdullah Nashih Ulwan sex education is an effort to teach, raise awareness, and explain sexual issues to children since they understand issues related to sex, instincts and marriage. So that when the child has become a youth and grows up Adults are expected to understand the affairs of life and can understand which things are lawful and unlawful. Sex education can also be interpreted as information about the anatomy, physiology of human sex, and the dangers of venereal disease [2].

Dr. Boyke provides a broader understanding that the notion of sex has a many dimensions. The first is the biological dimension of leadership. The second, the physiological dimension (has the function of the sex organs, including the process of menstruation, pregnancy and others). The third, the cultural dimension (different roles between men and women). The fourth, the social dimension, for example, family planning, venereal disease and others [3].

According to Law (UU) No. 36 of 2009 Articles 136-137 concerning Adolescent Health, the government provides information to find out about educational education.

Adolescence is very vulnerable to sexual harassment and abuse by peers and older age. Sexual harassment of adolescents by adults occurs because young adults are considered as innocent people, teenagers do not understand in terms of sex education, and think that everything is related to deviant sex. This allegation is caused by several influencing 
factors such as: (1) family (2) community (3) education (Syamsul, 2012). The lack of parental supervision of sexual education makes sexual harassment and violence increasingly rampant in adolescents [4].

Clara Kriswanto in (Fatmawati, 2018) said that sex education for children should have started early even at the age of 0-5 years (toddler). Precisely starting when the child is 3-4 years old, because at this age the child already understands the internal organs. (Fatmawati, 2018). In line with Nurul Chomaria's opinion, he said that sex education in children starts with an introduction to body anatomy, then increases to education about how to reproduce living creatures in humans and animals. According to Tretsakis in (Vivian, May, 2020) parents need to introduce sex education from an early age so that children easily accept the existence of the body as a whole and respect themselves, a healthy, honest and open education will foster respect and obedience towards their parents. prevent the occurrence of sexual and child abuse [5].

From the explanation above, the author makes an article about the need for educationlslamic sex in early understanding to parents and children how sex education is based on Islam so that it can be practiced in everyday life so that it can bring children to a good, safe, healthy, prosperous and happy life in everyday life day hereafter [6].

\section{2 | Methodology}

Research methods conducted by researchers are descriptive methods because the objects studied are events or changes in behavior. To get accurate data about sex learning strategies carried out by parents, researchers use questionnaires that contain several questions that must be filled by respondents. Kuisioner (angket) is a list of attachments filled by respondents, where the form of the attachment list is in the form of open or closed questions (Anto dajan, 1986: 39). In this case, the Researcher uses a list of attachments that contain closed questions so that the results of the questionnaire can be taken into account.

\section{3 | Result and Discussion}

Based on the results of the research questionnaire, $95 \%$ of parents perceive sex education as taboo, dirty, obscene, and the like. In fact, this assumption is not entirely true, it could 


\section{Qunselle}

Reviewed : 09-Dec-2021| Accepted : 28-Jan-2022 | Published : 29-Jan-2022

e-ISSN 2798-4230

DOI: $10.32923 /$ couns.v1i2.2063

$\mathrm{p}-\mathrm{ISSN} x \mathrm{x} x \mathrm{x}-\mathrm{x} x \mathrm{xx}$

Vol. 1, No. 2, Dec (2021)

even be wrong. Whereas here what is

There are several things about the meant by sex education is to teach, give understanding and explain issues related to sex, instincts and marriage to children since their minds begin to grow and are ready to understand the things above. Thus, when the child reaches the age of adolescence and can understand the problems of life, he knows which one is lawful and which one is unlawful, even straight Islamic behavior becomes a custom and tradition for the child. Sex education is an effort to teach, raise awareness and explain to children about issues related to sex, instinct and marriage according to Ulwan [7].

\section{1 | The Importance of Sexual Education in Children}

In general, people think that sex education only contains information about the genitals and various positions in sex. This of course will make parents feel worried. For this reason, it is necessary to straighten out the notion of sex education. Sex education seeks to put sex in the right perspective and change negative perceptions about sex [1]. 
internet, and even television shows that are now leading to such things. The impact of teenagers' lack of understanding about sex education, many negative things happen, such as high sex relations outside of marriage, unwanted pregnancies, transmission of the HIV virus and so on.

There are some opinions that say, "sex education" isshould be given by parents, because parents are the first madrasa for children. Especially children at puberty. Sex Education "Sex education" is very necessary to anticipate, know or prevent free sex activities and be able to avoid other negative impacts. Maybe we just realized the importance of education

sex because a lot of promiscuity appears among teenagers today. If we talk about promiscuity, this has actually been around for a long time, but now it seems to be getting worse. The promiscuity of teenagers can also be caused by increasingly advanced technology, as well as from modern factors in the global economy. But just blaming it all is also the right thing. The most important thing is how we are able to provide sex education to the younger generation [1].

\subsection{How Parents Provide Sexual Education to Teenagers.}

What should parents give in giving sexual education for children? The most important thing is to change the way we think as parents in providing sexual education to our children. Change the mindset that some people think of sexual education as a sexual relationship between men and women. Sex is not just a sexual relationship but a human relationship in which there are anatomy, physiology of organs between human relationships, namely men and women.

Also teach sex education from an early age by get used to living neatly and politely in dress, especially for girls. Next, what is told by children in opening up to their parents, then don't like to lecture, because children don't like being lectured, and use the right language. In addition, the most important thing is to use a religious approach, namely Islam.

In addition, also emphasize that the genitals are not may be shown honestly, and explain also if someone touches it without the parents knowing, then the little one must scream loudly 


\section{Qunselle}

Reviewed : 09-Dec-2021 | Accepted : 28-Jan-2022 | Published : 29-Jan-2022

and report to his parents. Thus, children can be protected against the rise of cases of sexual and sexual violence against children.

Some important things in providing sexual education in children include:

1. The way of conveying it must be reasonable and simple, do not look hesitant/ashamed.

2. The contents of the description submitted must be objective, but do not explain anything that is not, as if the aim is that the child will not ask again. Shallow/deep content of the description must be adjusted to the needs and stages of child development.

3. Sexual education must be given personally, because the breadth of knowledge and the rapid development of stages are not the same for every child. In the end, it should be noted that trying to carry out education needs to be repeated (repeated) besides that it is also necessary to find out how far something new can be absorbed by children, it is also necessary to remind and strengthen (reinforcement) [7].
4. teaching style events such as in schools. Biology talks are not only limited to facts, but also about values, emotions and soul. Don't worry that you've answered too many of your child's questions. They will always ask about what they don't understand.

5. Preschool age children also need to know how to protect against sexual abuse and abuse by adults. This means that parents must tell children that "no" to adults is something that is forbidden.

Don't wait until your child reaches the age of twenties to talk about puberty. They must already know the changes that occurred in the previous period [7].

\subsection{The Impact of the Lack of Sexual Education by Parents On.}

In this modernization era, the lack of sexual educationin children resulted in rampant free treatment sex. Free sex treatment is something that is rather common in society. Sex is the natural reproductive urge for a person to start a family as well as sexual attraction which is usually shared between one partner. Free sex treatment without regard to sex partners. Free sex is an unhealthy activity 
that brings a lot of negative things. The question is, what drives people to be trapped in this free sex treatment? So the answer is the perpetrator's lack of knowledge about the consequences of their sexual treatment.

The consequences of free sex treatment outside of marriage that can because HIV/AIDS and other diseases. Such as genital herpes, syphilis, gonorrhea, chlamydia, genital warts, hepatitis B, prostate cancer, cervical cancer and triconiasis for the perpetrators. Meanwhile, drugs can damage human health, both physically, emotionally, and user behavior.

\subsection{Views on Sex Education in Children.}

The views of the pros and cons of sex education depend on how we define sex education itself. If sex education is defined as providing information about the intricacies of anatomy and the process of human reproduction and prevention techniques (contraception) then anxiety arises. about sex that is given contextually, namely in the subject with the norms that apply in as well as various relationships and roles [8].

\section{4 | Closing}

Each person parents need to improve sex education for teenagers to stay awake religious norms and for the progress of making a generation of believers in the future, the research results are very good and need to be improved. Parents as first and foremost educators must provide their children with sex education because sex education plays a very important and influential role in society for the provision of life to maturity. The guidance that has been given really helps children to get sex education according to their needs according to the age level of each child, so that children develop naturally in accordance with Islamic norms and values. 


\section{Daftar Pustaka}

[1] Safita R. Peranan Orang Tua Dalam Memberikan Pendidikan Seksual Pada Anak. 2019;1-6. Available from: https://d1wqtxts1xzle7.cloudfront.net/5 9010342/httpe-

journal.iainjambi.ac.idindex.phpedubioa rticleview37634420190423-88796-

x88myn-with-cover-pagev2.pdf? Expires $=1628763439 \&$ Signature $=$ SJmNKpUL4ixTcbmxaHJitrMoWGx9Av 3 Ug3YdEnN3UxvUgBevsv8y1ZsS69Mun ObnwJu78v1z

[2] Mukri SG. Pendidikan Seks Usia Dini Dalam Perspektif Hukum Islam. Mizan J. Islam. Law 2018;3:1-20.

[3] Romdloni. Tinjauan Islam Terhadap Peranan Orang Tua Dalam Memberikan Pendidikan Seks Bagi Anak. 2017;3:95114.

[4] Andari DI, Woro O, Yuniastuti A. The Effect of Knowledge, Attitude, and Parents Behavior Towards Sex Education Parents With Sexual Violence Incident. Public Heal. Perspect. J. 2019;4:141-8.

[5] Early NA. Penting nya Pengetahuan Orang Tua Terhadap Pendidikan Seks Pada Anak Usia Dini. Academia.Edu [Internet] Available from: https://www.academia.edu/download/6 5315853/artikel_1_nike_tri_analisa.pdf

[6] Syekha. Urgensi pengenalan pendidikan seks pada anak dalam rumah tangga (tinjauan pendidikan islam). Angew. Chemie Int. Ed. 6(11), 951-952. 1967;1:524.

[7] Evania Yafie. Peran Orang Tua Dalam Memberikan Pendidikan Seksual Anak Usia Dini Evania. 2017;4:18-30.
[8] Muslim M, Ichwan I. Peran Orang Tua Dalam Pendidikan Seks Pada Anak Usia Dini. PELANGI J. Pemikir. dan Penelit. Islam Anak Usia Dini 2021;2:60-73. 